DOI https://doi.org/10.30525/978-9934-588-90-7-61

\title{
THE IMPACT OF MODERN INFORMATION TECHNOLOGIES ON THE TRAINING OF TECHNICAL TRANSLATION
}

\author{
Nykyporets S. S. \\ Lecturer at the Department of Foreign Languages \\ Vinnytsia National Technical University \\ Vinnytsia, Ukraine
}

Over the last 10-15 years, the nature of the translator's work and the requirements for it have changed significantly. First of all, the changes affected the written translation of scientific and technical, official and business documentation. Today, as a rule, it is no longer enough to simply translate text using a computer as a typewriter. A modern translator must possess a great number of various qualities and skills. What seems to be really crucial, apart from obvious proficiency with languages, is the ability to work with and adapt to new technologies. So, the content of professional training of a translator in a modern university should be carried out "taking into account the capabilities of modern information technology and focus on the formation of an educated, harmoniously developed personality capable of constant updating of scientific knowledge, professional mobility and rapid adaptation to changes in sociocultural sphere, management system and organization of labour in a market economy" [1].

The range of professional knowledge, skills and abilities of translators has expanded significantly and requires thorough general and professional methodological training, modern language and technical training. Active and interactive teaching methods are innovative methods, which are the most popular in today's market of educational services.

Taking into account the intensive development of the information society, the main place in the list of competencies that a modern translator should have is information competence. The high level of its formation will allow future translators to use information technology to effectively solve professional problems that take new forms. In the modern world of technology and the Internet, the combination of the study of translation and the use of computer technology is becoming relevant [2].

The use of new information technologies in the professional training of translators provides motivation for the formation of translation knowledge and skills. Today we live in a time of total informatization, i.e. the use of information technology for the production, processing, storage and 
dissemination of information and knowledge. In the process of training translators, more and more attention is paid to the use of multimedia courses with new unlimited possibilities, which open access to translation science and change the educational process.

In the process of training of translators, modern information technologies make it possible to organize the educational process with maximum efficiency by replenishing the active vocabulary, improving the skills of two-way translation, spelling and document processing.

The new multimedia tools that currently exist in the computer software and technology market have a number of advantages over traditional learning tools. The main ones are: variability of application at different stages of learning; economical use of study time; individualization of training; determining the depth and sequence of assimilation, the pace of work; reduction of monotonous work; creating a comfortable learning environment; activation of student's educational activity; intensification of training and increase of the level of motivation; formation of students' self-esteem and creation of conditions for independent work.

Translation programs have appeared for the needs of users in fast translation of various commercial, technical or Internet information, which is submitted in electronic form. The translation made by a computer is far from being perfect, but the text obtained as a result of the work of an electronic translator, allows in most cases to understand the essence of the document being translated. The document can be also edited with the help of knowledge of a foreign language and the subject area to which the translated information belongs.

One of the most famous machine translation programs on the Ukrainian market is ABBYY Lingvo, Trados, OmegaT, DejaVu, WordFast, etc. ABBYY Lingvo x5 includes more than 220 dictionaries, which contain more than 12.5 million articles for 20 languages. Thanks to the integration of recognition technology in ABBYY Lingvo $x 5$ it is possible to get instant translation by placing the cursor not only in the text but also in the image (in PDF files, videos and Flash videos, messages in game windows and movie subtitles). These programs support Drag \& Drop technology, OLE-automation, have an online help system, graphical dialog settings, as well as other controls, which makes these programs really popular among users [2].

The very first computer-assisted translation (CAT) software appeared almost 30 years ago. Its basic function was to store the translated texts in a translation memory and later use that memory to make translating recurring text easier and more efficient. This feature allowed translators to greatly accelerate their work, but the development continued from there. 
Unlike CAT tools, Machine Translation (MT) is not only a useful facilitator in the process of translating but directly generates a translation output. However, this kind of machine-translated text may subsequently have to be revised and edited by a human translator. This method might only be useful for large-scale projects and texts where readability and a particular communication style is of little importance.

The SDL Trados Studio [3] is a computer-assisted translation software suite, a successor to the older Translators Workbench originally developed by the German company Trados GmbH and currently available from SDL plc, a provider of customer experience cloud solutions. It is considered the market leader in providing translation software across the entire translation supply chain, including freelance translators, language service providers, corporate language departments and academic institutions. Translation of texts prepared in text editors is performed while preserving the text format (fonts, tables, paragraphs, indents, etc.).

SDL Trados Studio provides coherent translation within the subject areas covered by the dictionaries, and supports English-Ukrainian dictionaries and the Ukrainian grammar dictionary [4]. It is available in two editions tailored for the specific needs of individual translators and companies such as Language Service Providers (LSP). SDL Trados Studio Freelance [5] is the most popular edition for freelance translators, providing all the tools needed to translate and review work. SDL Trados Studio Professional [6] offers additional functionality for companies, allowing you to work with unlimited languages, manage translation projects and run Studio on a network.

One of the machine translation programs is Google Translate, a free multilingual neural machine translation service developed by Google, to translate text and websites from one language into another. [7]. It offers a website interface, a mobile app for Android and iOS, and an application programming interface that helps developers build browser extensions and software applications.

Machine translation systems have many shortcomings, as their developers have not managed to achieve the ultimate goal - to translate well without a human translator. Machine translation still remains imperfect. Thus, they form the basis of translation due to the literal processing of the text, but from many possible meanings of words they choose the one that is most commonly used. And this cannot be considered a professional translation in a certain field.

The most recent introduction to automated translations is an algorithm based on neural networks. The algorithm emulates the human brain, learning to parse words in the overall context of the sentence while comparing the 
similarity of individual words and phrases. This results in more accurate machine translations than ever before.

Thus, the use of modern information technologies in the formation of translation competence allows solving such tasks of the educational process as intensification of student learning, implementation of individual learning, saving time, controllability of results, use of the best world pedagogical experience, creation of conditions for practical use of knowledge and skills. However, along with the use of modern translation technologies, the future translation specialist must be fluent in a foreign language, translation techniques, be familiar with the field in which the translation is performed and possess the ability to work with and adapt to new technologies.

\section{References:}

1. Іваницька, Н. Б. Формування перекладацької компетенції в аспекті використання новітніх інформаційних технологій. Електронне наукове видання матеріалів IX Міжнародної науково-практичної конференції «Гуманізм та освіта». - Вінниця, 2006 URL: http://conf.vstu.vinnica.ua/ humed/2006/txt/06inbnit.php. (дата звернення: 24.10.2020)

2. Michael Borkovec. Modern Technologies in Translation. URL: https://www.zelenka-translations.com/blog/modern-technologies-intranslation (дата звернення: 24.10.2020)

3. SDL Trados Studio // Вікіпедія: вільна енциклопедія. URL: https://en.wikipedia.org/wiki/SDL_Trados_Studio (дата звернення: 24.10.2020)

4. SDL Trados Studio. Your complete translation toolkit. URL: https://www.sdltrados.com/products/trados-studio (дата звернення: 24.10.2020)

5. The complete translation environment for Freelance Translators. URL: https://www.sdltrados.com/products/trados-studio/freelance (дата звернення: 24.10.2020)

6. SDL Trados Studio Professional. URL: https://www.sdltrados.com/ products/trados-studio/professional (дата звернення: 24.10.2020)

7. Google Translate // Вікіпедія: вільна енциклопедія. URL: https://en.wikipedia.org/wiki/Google_Translate (дата звернення: 24.10.2020)

8. Bowker, L. Computer Aided Translation Technology: A Practical Introduction. Canada: University of Ottawa Press. URL: https://dialnet.unirioja.es/descarga/articulo/4925608.pdf (дата звернення: 20.10.2020) 